\title{
SYNTHESIS OF A NOVEL AMIDE DERIVATIVE OF VALPROIC ACID AND 1,3,4-THIADIAZOLE WITH ANTIEPILEPTIC ACTIVITY
}

Malygin $\mathrm{AS}^{1 \otimes}$, Demidova MA1 ${ }^{1}$ Skachilova SYa², Shilova $\mathrm{EV}^{2}$

${ }_{1}$ Tver State Medical University, Tver, Russia

${ }^{2}$ All-Russian Research Center for the Safety of Bioactive Substances, Staraya Kupavna, Moscow region, Russia

Valproates are commonly used to treat various forms of epilepsy. Problems accompanying their clinical application include drug resistance, adverse effects, acute and chronic toxicity. Safer anticonvulsants with improved efficacy can be obtained through the chemical modification of valproic acid structure. Thiadiazole-linked amide derivatives of valproates hold great promise because 1,3,4-thiadiazole can improve the drug's bioavailability and reduce its toxicity. The aim of this work was to synthesize a novel amide derivative of valproic acid and 1,3,4-thiadiazole exerting antiepileptic activity. The chemical structure of the synthesized valproate was studied by IR, proton NMR and 13C-NMR-spectroscopy, mass spectroscopy and elemental analysis. The purity and individuality of the compound was confirmed by thin-layer and high-performance liquid chromatography. Its antiepileptic activity was assessed in the test with intraperitoneally injected 250 mg/kg isoniazid and subsequent Probit analysis. The synthesized N-(5-ethyl-1,3,4-thiadiazol-2-yl)-2-propyl pentane amide (valprazolamide) had the following characteristics. ESI+MS: $\mathrm{m} / \mathrm{z} 256.1[\mathrm{M}+\mathrm{H}]^{+}$; MRM transitions: $\mathrm{m} / \mathrm{z} 256.1-\mathrm{m} / \mathrm{z} 81.0$ and $\mathrm{m} / \mathrm{z}$ 130.1. The valproate exerted antiepileptic activity against isoniazid-induced seizures in mice. In the test with isoniazid, $\mathrm{ED}_{50}$ of intraperitoneally injected VPZ was $126.8 \mathrm{mg} / \mathrm{kg}$ (95\% Cl: 65.5-245.4). Its therapeutic index was 7.3.

Keywords: antiepileptic drugs, valproic acid, 1,3,4-thiadiazole

Author contribution: Malygin AS — laboratory tests; data analysis; literature analysis; manuscript preparation; Demidova MA — study concept and design; manuscript preparation; Skachilova SYa, Shilova EV - synthesis and analysis of the compound; All authors equally contributed to the discussion of the study results.

Compliance with ethical standards: the study was approved by the Ethics Committee of Tver State Medical University (Protocol № 4 dated March 26, 2018). The animals were treated in compliance with the guidelines for laboratory practice in preclinical trials (Order 199n of the Russian Ministry of Healthcare dated April 1 , 2016, on the Good laboratory practice). All tests were carried out in accordance with the guidelines for preclinical trials of medicinal drugs and in compliance with the European Convention for the Protection of Vertebrate Animals Used for Experimental and other Scientific Purposes (Directive 2010/63/EU).

$\triangle$ Correspondence should be addressed: Alexandr S. Malygin

Sovetskaya, 4, Tver, 170100; dr.a.s.m@yandex.ru

Received: 17.01.2020 Accepted: 03.02.2020 Published online: 09.02.2020

DOI: $10.24075 /$ brsmu.2020.007

\section{СИНТЕЗ НОВОГО АМИДНОГО ПРОИЗВОДНОГО ВАЛЬПРОЕВОЙ КИСЛОТЫ И 1,3,4-ТИАДИАЗОЛА С ПРОТИВОЭПИЛЕПТИЧЕСКОЙ АКТИВНОСТЬЮ}

А. С. Малыгин ${ }^{1 凶}$, М. А. Демидова', С. Я. Скачилова², Е. В. Шилова²

1 Тверской государственный медицинский университет, Тверь, Россия

${ }^{2}$ Всесоюзный научный центр по безопасности биологически активных веществ, Старая Купавна, Московская область, Россия

Вальпроаты являются основными препаратами для лечения эпилепсии различных форм. Среди проблем, возникающих при их клиническом использовании, - фармакорезистентность, нежелательные побочные реакции, а также проявления острой и хронической интоксикации. Путем модификации химической структуры вальпроевой кислоты возможно создание более эффективных и безопасных антиконвульсантов. Перспективно получение тиадиазолиламидных производных вальпроатов, так как 1,3,4-тиадиазол может повышать биодоступность и снижать токсичность лекарственных средств. Целью работы был синтез нового амидного производного вальпроевой кислоты и 1,3,4-тиадиазола с противоэпилептической активностью. Химическую структуру синтезированного вальпроата исследовали методами ИК-спектроскопии, 1Н-ЯМР, 13С-ЯМР-спектроскопии, масс-спектроскопии и элементного анализа. Чистоту и индивидуальность подтверждали методами тонкослойной и высокоэффективной жидкостной хроматографий. Противоэпилептическую активность оценивали в тесте антагонизма с изониазидом (250 мг/кг, интраперитонеально) у мышей методом пробит-анализа. В результате исследования был получен N-(5-этил-1,3,4-тиадиазол-2-ил)-2-пропилпентанамид (вальпразоламид). ЕSI+-масс-спектр N-(5-этил-1,3,4-тиадиазол-2-ил)-2-пропилпентанамида - m/z 256,1 [M + H] $]^{+}$, MRM-переходы — m/z 256,1 - m/z 81,0 и m/z 130,1. Синтезированный вальпроат оказывал противоэпилептическое действие при изониазид-индуцированных судорогах у мышей. Значение ЕD тесте антагонизма с изониазидом составило 126,8 мг/кг (95\% ДИ: 65,5-245,4). Терапевтический индекс был равен 7,3.

Ключевые слова: противоэпилептические средства, вальпроевая кислота, 1,3,4-тиадиазол

Вклад авторов: А. С. Малыгин - экспериментальное исследование, анализ результатов, обзор публикаций по теме статьи, написание текста; М. А. Демидова - концепция и дизайн исследования, написание и редактирование текста; С. Я. Скачилова, Е. В. Шилова - синтез и анализ соединения; все авторы участвовали в обсуждении результатов.

Соблюдение этических стандартов: исследование одобрено этическим комитетом Тверского государственного медицинского университета (протокол № 4 от 26 марта 2018 г.). Подопытных животных содержали согласно правилам лабораторной практики при проведении доклинических исследований В РФ (Приказ МЗ РФ № 199н от 01.04.2016 «Правила надлежащей лабораторной практики»). Все эксперименты осуществляли в соответствии с методическими рекомендациями по проведению доклинических исследований лекарственных средств с соблюдением «Европейской конвенции о защите позвоночных животных, используемых для экспериментов или в иных научных целях» (Directive 2010/63/EU).

$\bowtie$ Для корреспонденции: Александр Сергеевич Малыгин ул. Советская, д. 4, г. Тверь, 170100; dr.a.s.m@yandex.ru

Статья получена: 17.01.2020 Статья принята к печати: 03.02.2020 Опубликована онлайн: 09.02.2020

DOI: $10.24075 /$ vrgmu.2020.007 
Over 75 million people worldwide suffer from epilepsy, and this number is continuously growing [1-2]. The key challenge of modern epileptology is drug resistance. Only $14.9 \%$ of epilepsy patients go into sustained remission. Seizures recur in $48.1 \%$ of patients, at a rate of up to 12 episodes a year [3-4]. Half of epilepsy patients are on multidrug antiseizure regimens. Some of them do not benefit from polytherapy or a regimen switch, which often result in a poor quality of life and an increased risk of adverse effects. Noncompliance is another serious concern: in Russia, $18.05 \%$ of epilepsy patients do not take their medications [5]. Optimization of antiepileptic pharmacotherapy is a crucial task facing epileptology.

Valproic (2-propylpentanoic) acid holds a special place in the arsenal of anticonvulsant drugs. It was first synthesized in 1882 by Beverly S. Burton and used as a solvent. Its anticonvulsant properties were discovered by accident in 1963 and have been used in clinical practice ever since [6]. Valproates are antiepileptic agents with a broad action spectrum and firstchoice drugs in patients with various forms of epilepsy. Longterm studies have demonstrated the efficacy of valproates against all forms of generalized epilepsy [7-9]. However, these compounds have adverse effects, including acute and chronic toxicity [10-12]. Valproates are highly teratogenic and therefore are not recommended to women of reproductive age [13]. Safer anticonvulsants with improved efficacy can be developed by modifying the chemical structure of valproic acid [14]

The aim of the study was to develop a novel anticonvulsant from a group of thiadiazole-linked amide derivatives of valproic acid.

\section{METHODS}

\section{Reagents}

The following reagents were used: 2-amino-5-ethyl-1,3,4thiadiazole (Acros Organics; Belgium), 2-propylpentanoic acid (Sigma Aldrich; USA), pyridine (LenReaktiv; Russia), isoniazid (Semashko Moschimfarmpreparaty; Russia), hydrochloric acid (LenReaktiv; Russia), 2-propanol (LenReaktiv; Russia), acetonitrile (LC-MS; Scharlau, Spain), ammonium acetate (Panreac AppliChem ITW reagents; USA), ethanol (Medchimprom; Russia), Milli-Q deionized water.

\section{Equipment}

The following equipment was used: an AB Sciex QTrap 3200 MD triple quadrupole mass spectrometer (Sciex; Singapore), an Agilent 1260 Infinity II high-performance liquid chromatography system (Agilent Technologies; Germany), TLC plates (silica gel 60 F 254) (Merck; Germany), a Bruker Avance-400 spectrometer (Bruker; Germany), an Agilent Cary 630 FTIR spectrometer (Agilent; Germany), an EA 1108 analyzer for elemental analysis (Carlo Erba Instruments; Italy), Acculab ALC-80d4 analytical scales (Acculab; USA), an Eppendorf 5810R centrifuge with a cooled rotor chamber (Eppendorf; Germany), a Millipore DirectQ UV water purification system (Millipore SAS; France), an Elmi V-3 vortex mixer (Elmi; Latvia), an Elmi S-3 shaker (Elmi; Latvia), a Thermit dry-block heater (DNA-Technology; Russia), Eppendorf (Eppendorf; Germany) and Black Thermo (Thermo Fisher Scientific; Russia) automated dispensers.

\section{Identification methods}

The chemical structure of the synthesized valproate ( $\mathrm{N}$-(5ethyl-1,3,4-thiadiazol-2-yl)-2-propyl pentane amide) was studied using IR, proton NMR and 13C-NMR spectroscopy, mass-spectroscopy and elemental analysis. Purity of the obtained compound was evaluated by thin-layer (TLC) and high-performance liquid chromatography (HPLC).

\section{Tests of antiepileptic activity}

The antiepileptic activity of the synthesized valproate was tested using a valproate antagonist (isoniazid). Generalized tonicclonic seizures were induced in male outbred SNK mice (19-21 g body weight, $n=40$ ) by an intraperitoneal injection of $250 \mathrm{mg} / \mathrm{kg}$ isoniazid [15]. The animals were kept in a vivarium of Tver State Medical University at a constant temperature of $22 \pm 2{ }^{\circ} \mathrm{C}$ under a 12/12 light/dark cycle (lights on from 08:00 to 20:00). The animals had free access to food and water. The mice were randomized into 5 groups: the control group (isoniazidinduced seizures) and experimental groups (intraperitoneal administration of $75,150,300$ and $450 \mathrm{mg} / \mathrm{kg}$ valproate $40 \mathrm{~min}$ before the isoniazid injection). Video observation lasted for 3 hours to assess latency to the first seizure, record the onset of

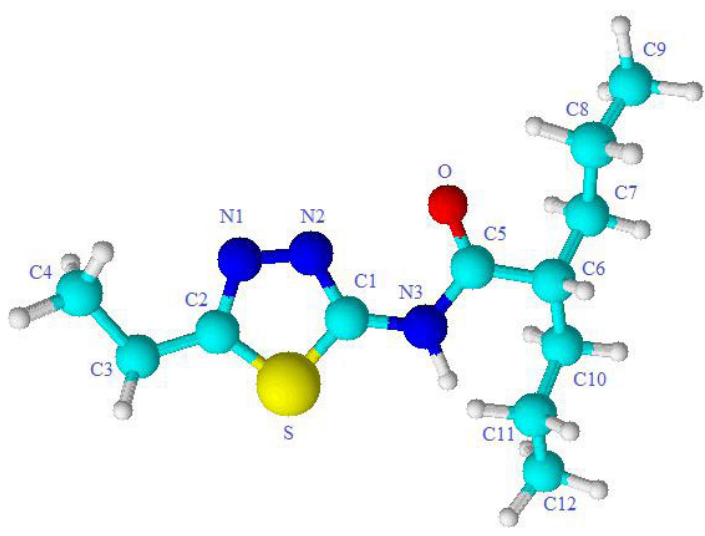

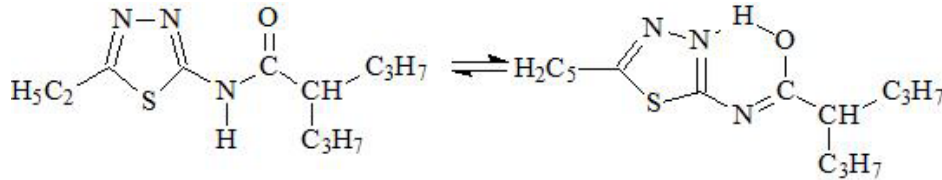

Fig. 1. N-(5-ethyl-1,3,4-thiadiazol-2-yl)-2-propyl pentane amide

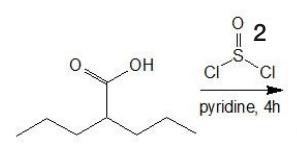

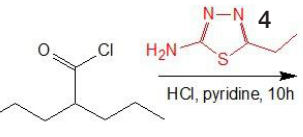

3

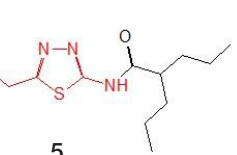

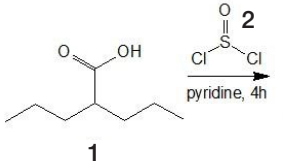
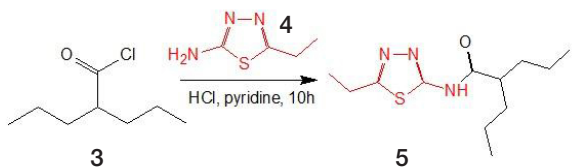

Fig. 2. A schematic representation of $\mathrm{N}$-(5-ethyl-1,3,4-thiadiazol-2-yl)-2-propyl pentane amide synthesis, $1-2$-propylpentanoic acid; $2-$ thionyl chloride; $3-$ 2-propylpentanoic acid chloroanhydride; 4 - 2-amino-5-ethyl-1,3,4-thiadiazole; 5 - N-(5-ethyl-1,3,4-thiadiazol-2-yl)-2- propyl pentane amide 
clonic and tonic seizures and the outcomes (death or survival). We also calculated $\mathrm{ED}_{50}$ (the median effective doze required to ensure survival of $50 \%$ of the animals in the test) and the therapeutic index $\left(\mathrm{TI}=\mathrm{DL}_{50} / \mathrm{ED}_{50}\right.$, i.e. the ratio of the median lethal dose to the median effective dose).

\section{Statistical analysis}

Statistical analysis was carried out in BioStat 2009 (AnalystSoft; USA). The results of the experiment were analyzed using descriptive statistics. The normality of data distribution was tested using the Shapiro-Wilk test. Group means were compared by one-way ANOVA with post-hoc Tukey HSD. Categorical variables were compared using Fisher's exact test. In this work, the data are presented as $m \pm$ SEM. Finney Probit analysis was applied to calculate $\mathrm{ED}_{50}$

\section{RESULTS}

\section{Synthesis}

Fig. 1 shows the synthesized thiadiazole-linked amide derivative of valproic acid, $\mathrm{N}$-(5-ethyl-1,3,4-thiadiazol-2-yl)-2-propyl

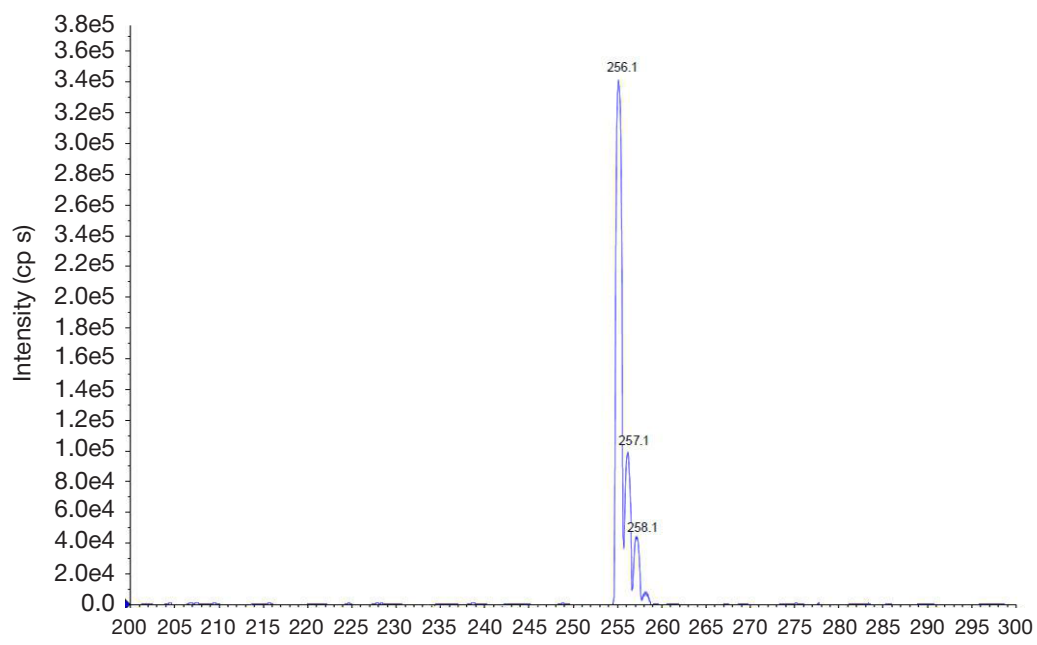

Fig. 3. $\mathrm{ESI}^{+}$-mass-spectrum of $\mathrm{N}$-(5-ethyl-1,3,4-thiadiazol-2-yl)-2-propyl pentane amide $\left([\mathrm{M}+\mathrm{H}]^{+}\right)$

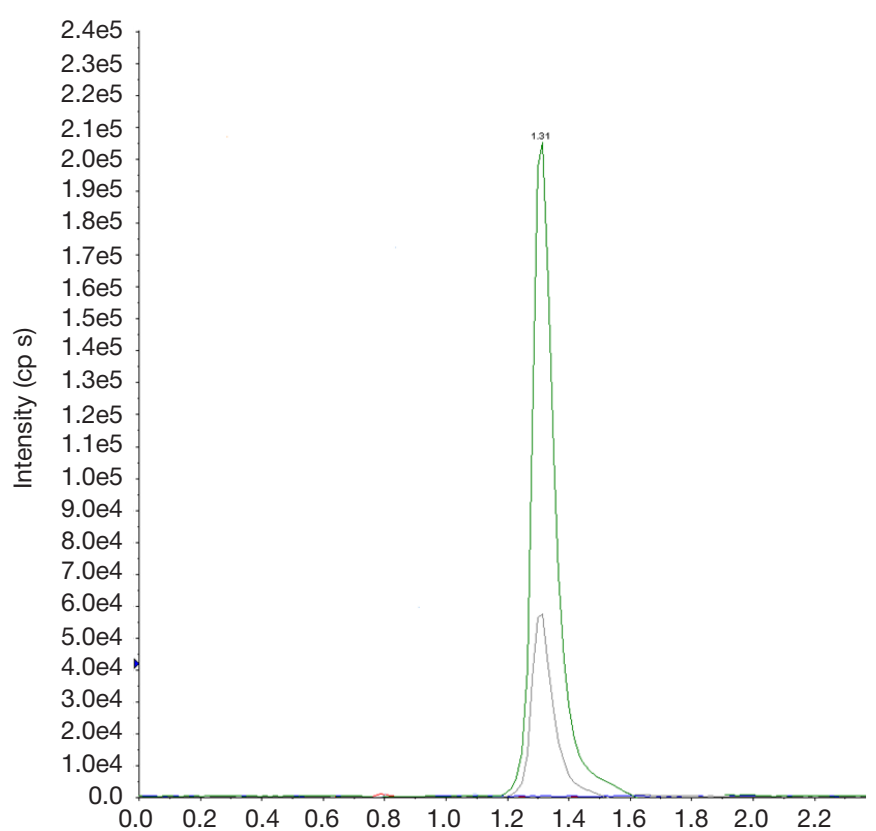

Fig. 4. A chromatogram of $\mathrm{N}$-(5-ethyl-1,3,4-thiadiazol-2-yl)-2-propyl pentane amide pentane amide. Its molecular formula is $\mathrm{C}_{12} \mathrm{H}_{21} \mathrm{~N}_{3} \mathrm{OS}$. The laboratory name for the compound is valprazolamide (VPZ).

The synthesis of this novel anticonvulsant agent can be broken down in the following stages: halogenation of 2-propylpentanoic acid by thionyl chloride; stochiometric interaction of the resulting 2-propylpentanoic acid chloroanhydride with 2-amino-5-ethyl-1,3,4-thiadiazole; acidification of the reaction mix by $\mathrm{HCl}(\mathrm{pH}$ lowered to 1-2) at $5^{\circ} \mathrm{C}$ for getting a crystalline precipitate (Fig. 2).

The synthesized compound was purified as described below. Water-soluble impurities were removed by washing the reaction product with cooled water; then, the product was refiltered and recrystallized in 2-propanol after preliminary vacuum-drying at $10 \mathrm{mmHg}$ until its mass was constant $(67 \%$ yield). Purification quality was assessed with TLC and HPLC.

\section{Description and identification of $\mathrm{N}$-(5-ethyl-1,3,4-thiadiazol-2-yl)-2-propyl pentane amide}

The synthesized pharmaceutical substance is a yellowish-white crystalline powder with a molar mass of $255.14 \mathrm{~g} / \mathrm{mol}$ and a melting point of $93-94{ }^{\circ} \mathrm{C}$. The powder is barely soluble in water but well soluble in alcohol, acetonitrile and other organic solvents. 
The chemical structure of $\mathrm{N}$-(5-ethyl-1,3,4-thiadiazol2-yl)-2-propyl pentane amide $\left(\mathrm{C}_{12} \mathrm{H}_{21} \mathrm{~N}_{3} \mathrm{OS}\right)$ was confirmed by elemental analysis and spectroscopy. The predicted content of $\mathrm{C}$ in $\mathrm{C}_{12} \mathrm{H}_{21} \mathrm{~N}_{3} \mathrm{OS}$ was $56.44 \% ; \mathrm{H}, 8.29 \%$; $\mathrm{N}, 16.45 \%$; $6.26 \% ; \mathrm{S}, 12.56 \%$. According to the results of the elemental analysis, the actual content of the elements was as follows: $\mathrm{C}$, 56.39\%; H, 8.34\%; N, 16.41\%; O, 6.26\%; S, 12.60\%, which was consistent with the chemical structure of the synthesized compound.

Spectroscopy results are shown below. IR spectra $(\mathrm{KBr}$ pelleting technique), v/ $\mathrm{cm}^{-1}$ : 3302, $3030(\mathrm{NH}), 2981,2959$, $2860(\mathrm{CH}), 1545$ (NHCO); ${ }^{1} \mathrm{H}-\mathrm{NMR}\left(400 \mathrm{MHz}, \mathrm{DMSO}_{-} \mathrm{d}_{6}\right)$ $\delta$ ppm: $0.97\left(\mathrm{~s}, 3 \mathrm{H}, \mathrm{CH}_{3}\right), 1.33\left(\mathrm{~s}, 2 \mathrm{H}, \mathrm{CH}_{2}\right), 1.41-1.50(\mathrm{~m}$, 4H), 2.65 (s, 2H, $\mathrm{CH}_{2}$ ), 10.63 (s, $\left.1 \mathrm{H}, \mathrm{NH}\right) ;{ }^{13} \mathrm{C}-\mathrm{NMR}(400 \mathrm{MHz}$, DMSO-d $) \delta$ ppm: 13.48, 13.66, 20.06, 24.70, 35.27, 43.22, 155.85, 156.5, 175.00; ESI+MS: m/z $256.1\left([\mathrm{M}+\mathrm{H}]^{+}\right)$; MRM transitions: $\mathrm{m} / \mathrm{z} 256.1 \rightarrow \mathrm{m} / \mathrm{z} 81.1$ and $\mathrm{m} / \mathrm{z}$ 130.1. ESI ${ }^{+} \mathrm{MS}$ for $\mathrm{N}$-(5-ethyl-1,3,4-thiadiazol-2-yl)-2-propyl pentane amide is shown in Fig. 3.

Purity of the synthesized anticonvulsant agent was assessed by HPLC at $50^{\circ} \mathrm{C}$ using a Phenomenex synergi $4 \mu \mathrm{m}$ C18 Fusion column $(2 \times 50 \mathrm{~mm})$. For elution, $90: 10$ methanol : deionized water and $0.1 \%$ ammonium acetate were used. Retention time was $1.31 \mathrm{~min}$ (Fig. 4).

\section{Antiepileptic activity tests in a mouse model of isoniazid-induced seizures}

Intraperitoneal administration of $250 \mathrm{mg} / \mathrm{kg}$ isoniazid induced generalized tonic-clonic seizures resulting in the death of all control animals. An injection of VPZ given 40 min before isoniazid administration had a dose-dependent effect on the progression of isoniazid-induced seizures in mice $(p<0.0001$; one-way ANOVA). A $75 \mathrm{mg} / \mathrm{kg}$ VPZ dose significantly increased seizure latency (by 1.5-fold) in the experimental groups in comparison with the control animals, but did not prevent seizures or animal death. At 150 and $300 \mathrm{mg} / \mathrm{kg}$, VPZ increased seizure latency and reduced the death rate. In a test with $450 \mathrm{mg} /$ $\mathrm{kg}$ VPZ, no seizures were observed for $3 \mathrm{~h}$ following isoniazid administration (see Table).

Probit analysis revealed that $\mathrm{ED}_{50}$ of intraperitoneally injected VPZ was $126.8 \mathrm{mg} / \mathrm{kg}$ (95\% Cl: 65.5-245.4) in the test with VPZ antagonist. The therapeutic index was 7.3.

\section{DISCUSSION}

Candidate anticonvulsant agents must be effective against refractory epilepsy, have fewer side effects and better tolerability, as well as the ability to slow down progression of the disease and modify its course. Additional advantages include linear pharmacokinetics, simplicity of titration in the clinical setting, ancillary therapeutic effects such as relief of neuropathic pain. Such candidates are usually searched for among novel molecules or developed based on the derivatives of known anticonvulsants.

The possibility of creating new-generation valproates has been shown in the literature [16]. The teratogenicity of their amide analogs is significantly lower than that of valproic acid [17]. Valproic acid amides demonstrate antiepileptic [18], antineuropathic [19-20], antiviral [21-22] and some other properties. A number of 1,3,4-thiadiazole derivatives, including those that contain a valproic acid residue, have been reported to exert anticonvulsant activity [23]. The majority of such derivatives have higher bioavailability and are less toxic than their analogs. This is also true for the valproate synthesized in this study, containing 1,3,4-thiadiazole. Using a mouse model, researchers have demonstrated that $D L_{50}$ of an intraperitoneally injected 1,3,4-thiadiazole-linked amide derivative of valproic acid is 1.8 times higher than that of valproic acid [24]. The antiepileptic effect of the synthesized valproate has been confirmed in maximal electroshock seizure models and pentylenetetrazole-induced seizure models in mice [25-26]. Considering that VPZ was the most active in a test with a GABAA-receptor antagonist (pentylenetetrazole), we studied the effect of this valproate on the seizures induced by another GABA antagonist isonicotinylhydrazide (isoniazid). The proconvulsant effect of isoniazid is linked to the inhibition of GABA synthesis resulting from isoniazid antagonism towards pyridoxal phosphate, a coenzyme of glutamate decarboxylase that catalyzes glutamate conversion into GABA. Antituberculous therapy with isoniazid can cause serious complications in the form of seizures often described as status epilepticus. Isoniazid-induced seizures are poorly controlled by conventional anticonvulsants and cannot always be prevented by pyridoxine intake [27-28]. Valproates are known to inhibit development of isoniazid-induced seizures in a dose-dependent fashion [29]. Our study demonstrates that an injection of $\mathrm{N}$-(5-ethyl1,3,4-thiadiazol-2-yl)-2-propyl pentane amide before seizure modeling increased latency to the first seizure and reduced the death rate in mice in the isoniazid test. Based on these findings, $\mathrm{N}$-(5-ethyl-1,3,4-thiadiazol-2-yl)-2-propyl pentane amide can be considered a candidate antiepileptic drug with an improved safety profile.

\section{CONCLUSIONS}

The results of the study confirm that modification of valproic acid with 1,3,4-thiadiazole holds promise for discovering novel anticonvulsant candidate drugs. The advantage of the synthesized $\mathrm{N}$-(5-ethyl-1,3,4-thiadiazol-2-yl)-2-propyl pentane amide is its

Table. The effect of N-(5-ethyl-1,3,4-thiadiazol-2-yl)-2-propyl pentane amide (VPZ) on the latency to the first seizure and survival of mice in the test with the VPZ antagonist isoniazid ( $250 \mathrm{mg} / \mathrm{kg}$ injected intraperitoneally)

\begin{tabular}{|c|c|c|c|c|}
\hline Test & Dose, mg/kg & $\begin{array}{l}\text { LS1, } \min \\
m \pm \text { SEM }\end{array}$ & $\begin{array}{l}\text { Number of surviving mice /total number } \\
\text { of mice }\end{array}$ & Survival, $\%$ \\
\hline $\mathrm{NaCl} \mathrm{IS}+\mathrm{INH}$ & - & $31.25 \pm 2.03$ & $0 / 8$ & 0 \\
\hline $\mathrm{VPZ}+\mathrm{INH}$ & 75 & $47.75 \pm 2.42^{\star}$ & $0 / 8$ & 0 \\
\hline $\mathrm{VPZ}+\mathrm{INH}$ & 150 & $72.13 \pm 4.28^{\star}$ & $5 / 8$ & $62.5^{\#}$ \\
\hline $\mathrm{VPZ}+\mathrm{INH}$ & 300 & $93.75 \pm 4.77^{\star}$ & $7 / 8$ & $87.5^{\#}$ \\
\hline $\mathrm{VPZ}+\mathrm{INH}$ & 450 & - & $8 / 8$ & $100^{\#}$ \\
\hline
\end{tabular}

Note: * - statistically significant difference between the experimental group and the control animals (mice with isoniazid-induced seizures treated with NaCl IS before the isoniazid injection) ( $p<0.05$; one-way ANOVA with post-hoc Tukey HSD); \# - statistically significant difference between the experimental group and the control ( $p<0.05$; Fisher's exact test). VPZ is valprazolamide ( $\mathrm{N}$-(5-ethyl-1,3,4-thiadiazol-2-yl)-2-propyl pentane amide); INH is isoniazid; NaCl IS is the isotonic solution of sodium chloride; LS1 is latency to the first seizure. 
ability to prevent development of isoniazid-induced seizures. The compound is not soluble in water, which is a disadvantage, since it hinders manufacturing of its injectable formulations. Further research will be focused on the improvement of the compound's biological and pharmaceutical properties by loading it onto $\beta$-cyclodextrin nanocapsules. Methods of $\mathrm{N}$-(5-ethyl-1,3,4thiadiazol-2-yl)-2-propyl pentane amide identification can also be applied to test its originality and used in pharmacokinetic studies.

\section{References}

1. Singh A, Trevick S. The epidemiology of global epilepsy. Neurol Clin. 2016 Nov; 34 (4): 837-47. PubMed PMID: 27719996.

2. Avakyan GN. Questions modern epileptology. Epilepsy and paroxysmal conditions. 2015; 7 (4): 16-21. Russian.

3. Avakyan GN, Belousova ED, Burd SG, Vlasov PN, Ermolenko NA Kissin MY, et al. Current trends in epileptology: priorities, challenges, tasks and solutions. Epilepsy and paroxysmal conditions. 2019; 11 (4): 395-406. Russian.

4. Kalilani L, Sun X, Pelgrims B, Noack-Rink V, Villanueva V. The epidemiology of drug-resistant epilepsy: A systematic review and meta-analysis. Epilepsia. 2018; 59 (12): 2179-93. PubMed PMID: 30426482.

5. Avakyan GN, Vlasov PN, Zhidkova IA, Karlov VA, Lebedeva AV, Mikhalovska-Karlova EP, et al. Conclusion of the Council of Experts on the use of valproate in patients with epilepsy. Neurology, neuropsychiatry, psychosomatics. Epilepsy and paroxysmal conditions. 2015; 7 (1): 69. Russian.

6. Tomson T, Battino D, Perucca E. The remarkable story of valproic acid. Lancet Neurol. 2016 Feb; 15 (2): 141. PubMed PMID: 28463122.

7. Voronkova KV, Nikitin AE, Rudakova IG, Vlasov PN, Burd SG, Lebedeva AV, et al. Today's choice of antiepileptic therapy: stages and recommendations. Epilepsy and paroxysmal conditions. 2018; 10 (2): 74-81. Russian.

8. Mukhin KYu, Petrukhin AS, Mironov MB. Sodium valproate (Depakine) in achieving remission in patients with idiopathic generalized epilepsy (long-term follow-up). Neurological journal. 2004; (4): 34-39. Russian.

9. Perucca E. Pharmacological and therapeutic properties of valproate: a summary after 35 years of clinical experience. CNS Drugs. 2012; 16 (10): 695-714.

10. Badalyan OL, Burd SG, Savenkov AA, Avakyan GG, Yutskova EV, Avakyan GN. Comparative evaluation of the efficacy and safety of valproic acid derivatives. Epilepsy and paroxysmal conditions. 2014; 6 (2): 39-44. Russian.

11. Schneider NA, Dmitrenko DV. Chronic intoxication with valproic acid in epileptology: diagnosis and treatment. Neurology, neuropsychiatry, psychosomatics. 2016; 8 (2): 94-99. Russian.

12. Sztajnkrycer MD. Valproic acid toxicity: overview and management. J Toxicol Clin Toxicol. 2002; 40 (6): 789-801. PubMed PMID:12475192.

13. Tomson T, Battino D, Perucca E. Valproic acid after five decades of use in epilepsy: time to reconsider the indications of a timehonoured drug. Lancet Neurol. 2016 Feb; 15 (2): 210-8. PubMed PMID: 26655849.

14. Pessah N, Yagen B, Hen N, Shimshoni JA, Wlodarczyk B, Finnell RH, Bialer M. Design and pharmacological activity of glycinamide and $\mathrm{N}$-methoxy amide derivatives of analogs and constitutional isomers of valproic acid. Epilepsy Behav. 2011 Nov; 22 (3): 461 8. PubMed PMID:21959082.

15. Sun $X Y$, Wei $C X$, Deng $X Q$, Sun $Z G$, Quan ZS. Evaluation of the anticonvulsant activity of 6-(4-chlorophenyoxy)-tetrazolo[5,1-a] phthalazine in various experimental seizure models in mice. Pharmacological Reports: PR, 01 Mar 2010, 62 (2): 273-7. PubMed PMID: 20508282

16. Trojnar MK, Wierzchowska-Cioch E, Krzyzanowski M, Jargiełło M, Czuczwar SJ. New generation of valproic acid. Pol J Pharmacol.
2004 May-Jun; 56 (3): 283-8. PubMed PMID: 15215557.

17. Lin YL, Bialer M, Cabrera RM, Finnell RH, Wlodarczyk BJ. Teratogenicity of valproic acid and its constitutional isomer, amide derivative valnoctamide in mice. Birth Defects Res. 2019 Aug 15; 111 (14):1013-23. PubMed PMID: 30325584.

18. Haines KM, Matson LM, Dunn EN1, Ardinger CE, Lee-Stubbs R, Bibi D, McDonough JH, Bialer M. Comparative efficacy of valnoctamide and sec-butylpropylacetamide (SPD) in terminating nerve agentinduced seizures in pediatric rats. Epilepsia. 2019 Feb; 60 (2): 315-21. PMID: 30615805

19. Kaufmann D, Bialer M, Shimshoni JA, Devor M, Yagen B. Synthesis and evaluation of antiallodynic and anticonvulsant activity of novel amide and urea derivatives of valproic acid analogues. J Med Chem. 2009 Nov 26; 52 (22): 7236-48. PubMed PMID 19877649

20. Samur DN, Arslan R, Aydın S, Bektas N. Valnoctamide: The effect on relieving of neuropathic pain and possible mechanisms. Eur J Pharmacol. 2018 May 15; (827): 208-14. PubMed PMID: 29522726.

21. Praena B, Bello-Morales R, de Castro F, López-Guerrero JA. Amidic derivatives of valproic acid, valpromide and valnoctamide, inhibit HSV-1 infection in oligodendrocytes. Antiviral Res. 2019 Aug; (168): 91-99. PubMed PMID: 31132386.

22. Ornaghi S, Hsieh LS, Bordey A, Vergani P, Paidas MJ, van den Pol AN. Valnoctamide Inhibits Cytomegalovirus Infection in Developing Brain and Attenuates Neurobehavioral Dysfunctions and Brain Abnormalities. J Neurosci. 2017 Jul 19; 37 (29): 687793. PubMed PMID: 28630251

23. Jain AK, Sharma S, Vaidya A, Ravichandran V, Agrawal RK. 1,3,4-Thiadiazole and its Derivatives: A Review on Recent Progress in Biological Activities. Chem Biol Drug Des. 2013; (81): 557-76. PubMed PMID: 23452185.

24. Malygin AS. Assessment of acute toxicity and neurotoxicity of a new amide derivative of valproic acid and 1,3,4-thiadiazole. The medicine. 2019 (3): 37-46. Russian.

25. Malygin AS. Study on the antiepyleptic activity of the new amide derivative of valproic acid and 1,3,4-thiadiazole. Epilepsy and paroxysmal conditions. 2019; 11 (4): 357-63. Russian.

26. Skachilova SYa, Malygin AS, Popov NS, Demidova MA, avtory; Vladelets patenta: «Vsesoyuznyy nauchnyy tsentr po bezopasnosti biologicheski aktivnykh veshchestv». N-(5-etil-1,3,4-tiadiazol-2il)-2-propilpentanamid, obladayushchiy protivoepilepticheskoy i obezbolivayushchey aktivnostyami. Patent RU № 2672887. 13.03. 2018. Russian.

27. Bernasconi R, Klein M, Martin P, Portet C, Maître L, Jones RS, et al. The specific protective effect of diazepam and valproate against isoniazid-induced seizures is not correlated with increased GABA levels. J Neural Transm.1985; 63 (2): 169-89. PubMed PMID: 3930661.

28. Asehinde S, Ajayi A, Bakre A, Omorogbe O, Adebesin A, Umukoro S. Effects of Jobelyn ${ }^{\circledast}$ on Isoniazid-Induced Seizures, Biomarkers of Oxidative Stress and Glutamate Decarboxylase Activity in Mice Basic Clin Neurosci. 2018 Nov-Dec; 9 (6): 389-96. PMID: 30719253.

29. Minns AB, Ghafouri N, Clark RF. Isoniazid-induced status epilepticus in a pediatric patient after inadequate pyridoxine therapy. Pediatr Emerg Care. 2010 May; 26 (5): 380-1. PubMed PMID: 20453796 


\section{Литература}

1. Singh A, Trevick S. The epidemiology of global epilepsy. Neurol Clin. 2016 Nov; 34 (4): 837-47. PubMed PMID: 27719996.

2. Авакян Г. Н. Вопросы современной эпилептологии. Эпилепсия и пароксизмальные состояния. 2015; (4): 16-21.

3. Авакян Г. Н., Белоусова Е. Д., Бурд С. Г., Власов П. Н., Ермоленко Н. А., Киссин М. Я. и др. Проблемы эпилептологии. Ключевые приоритеты, задачи, вызовы и способы их решения. Эпилепсия и пароксизмальные состояния. 2019; 11 (4): 395-406.

4. Kalilani L, Sun X, Pelgrims B, Noack-Rink V, Villanueva V. The epidemiology of drug-resistant epilepsy: A systematic review and meta-analysis. Epilepsia. 2018; 59 (12): 2179-93. PubMed PMID: 30426482

5. Авакян Г. Н., Власов П. Н., Жидкова И. А., Карлов В. А., Лебедева А. В., Михаловска- Карлова Е. П. и др. Заключение Совета экспертов по применению вальпроатов у пациенток с эпилепсией. Неврология, нейропсихиатрия, психосоматика. Эпилепсия. 2015; (1): 63-64.

6. Tomson T, Battino D, Perucca E. The remarkable story of valproic acid. Lancet Neurol. 2016 Feb; 15 (2): 141. PubMed PMID: 28463122

7. Воронкова К. В., Никитин А. Э., Рудакова И. Г., Власов П. Н., Бурд С. Г., Лебедева А. В. и др. Современный выбор антиэпилептической терапии: этапы и рекомендации. Эпилепсия и пароксизмальные состояния. 2018; 10 (2): 74-81.

8. Мухин К. Ю., Петрухин А. С., Миронов М. Б. Вальпроат натрия (Депакин) в достижении ремиссии у больных идиопатической генерализованной эпилепсией (долгосрочный катамнез). Неврологический журнал. 2004; (4): 34-39.

9. Perucca E. Pharmacological and therapeuti properties of valproate: a summary after 35 years of clinical experience. CNS Drugs. 2012; 16 (10): 695-714.

10. Бадалян О. Л., Бурд С. Г., Савенков А. А., Авакян Г. Г., Юцкова Е. В., Авакян Г. Н. Сравнительная оценка эффективности и безопасности производных вальпроевой кислоты: опыт применения. Эпилепсия и пароксизмальные состояния. 2014; 6 (2): 39-44.

11. Шнайдер Н. А., Дмитренко Д. В. Хроническая интоксикация вальпроевой кислотой в эпилептологии: диагностика и лечение. Неврология, нейропсихиатрия, психосоматика. 2016; 8 (2): 94-99.

12. Sztajnkrycer MD. Valproic acid toxicity: overview and management. J Toxicol Clin Toxicol. 2002; 40 (6): 789-801. PubMed PMID:12475192.

13. Tomson T, Battino D, Perucca E. Valproic acid after five decades of use in epilepsy: time to reconsider the indications of a timehonoured drug. Lancet Neurol. 2016 Feb; 15 (2): 210-8. PubMed PMID: 26655849

14. Pessah N, Yagen B, Hen N, Shimshoni JA, Wlodarczyk B, Finnell RH, Bialer M. Design and pharmacological activity of glycinamide and $\mathrm{N}$-methoxy amide derivatives of analogs and constitutional isomers of valproic acid. Epilepsy Behav. 2011 Nov; 22 (3): 461-8. PubMed PMID:21959082.

15. Sun $X Y$, Wei $C X$, Deng $X Q$, Sun $Z G$, Quan ZS. Evaluation of the anticonvulsant activity of 6-(4-chlorophenyoxy)-tetrazolo[5,1-a] phthalazine in various experimental seizure models in mice. Pharmacological Reports: PR, 01 Mar 2010, 62 (2): 273-7. PubMed PMID: 20508282.

16. Trojnar MK, Wierzchowska-Cioch E, Krzyzanowski M, Jargiełło M,
Czuczwar SJ. New generation of valproic acid. Pol J Pharmacol. 2004 May-Jun; 56 (3): 283-8. PubMed PMID: 15215557.

17. Lin $\mathrm{YL}$, Bialer $\mathrm{M}$, Cabrera RM, Finnell RH, Wlodarczyk BJ. Teratogenicity of valproic acid and its constitutional isomer, amide derivative valnoctamide in mice. Birth Defects Res. 2019 Aug 15; 111 (14): 1013-23. PubMed PMID: 30325584.

18. Haines KM, Matson LM, Dunn EN1, Ardinger CE, Lee-Stubbs R, Bibi D, McDonough $\mathrm{JH}$, Bialer M Comparative efficacy of valnoctamide and sec-butylpropylacetamide (SPD) in terminating nerve agent-induced seizures in pediatric rats. Epilepsia. 2019 Feb; 60 (2): 315-21. PMID: 30615805.

19. Kaufmann D, Bialer M, Shimshoni JA, Devor M, Yagen B. Synthesis and evaluation of antiallodynic and anticonvulsant activity of novel amide and urea derivatives of valproic acid analogues. $J$ Med Chem. 2009 Nov 26; 52 (22): 7236-48. PubMed PMID 19877649.

20. Samur DN, Arslan R, Aydın S, Bektas N. Valnoctamide: The effect on relieving of neuropathic pain and possible mechanisms. Eur J Pharmacol. 2018 May 15; (827): 208-14. PubMed PMID: 29522726.

21. Praena B, Bello-Morales R, de Castro F, López-Guerrero JA Amidic derivatives of valproic acid, valpromide and valnoctamide, inhibit HSV-1 infection in oligodendrocytes. Antiviral Res. 2019 Aug; (168): 91-99. PubMed PMID: 31132386.

22. Ornaghi $S$, Hsieh LS, Bordey A, Vergani $P$, Paidas MJ, van den Pol AN. Valnoctamide Inhibits Cytomegalovirus Infection in Developing Brain and Attenuates Neurobehavioral Dysfunctions and Brain Abnormalities. J Neurosci. 2017 Jul 19; 37 (29): 6877-93. PubMed PMID: 28630251.

23. Jain AK, Sharma S, Vaidya A, Ravichandran V, Agrawal RK. 1,3,4-Thiadiazole and its Derivatives: A Review on Recent Progress in Biological Activities. Chem Biol Drug Des. 2013; (81): 557-76. PubMed PMID: 23452185.

24. Малыгин А. С. Оценка острой токсичности и нейротоксичности нового амидного производного вальпроевой кислоты и 1,3,4-тиадиазола. Медицина. 2019; (3): 37-46.

25. Малыгин А. С. Исследование противоэпилептической активности нового амидного производного вальпроевой кислоты и 1,3,4-тиадиазола. Эпилепсия и пароксизмальные состояния. 2019; 11 (4): 357-63.

26. Скачилова С. Я., Малыгин А. С., Попов Н. С., Демидова М. А., авторы; Владелец патента: «Всесоюзный научный центр по безопасности биологически активных веществ». N-(5-этил1,3,4-тиадиазол-2-ил)-2-пропилпентанамид, обладающий противоэпилептической и обезболивающей активностями. Патент РФ № 2672 887. 13.03. 2018.

27. Asehinde S, Ajayi A, Bakre A, Omorogbe O, Adebesin A, Umukoro S. Effects of Jobelyn ${ }^{\circledast}$ on Isoniazid-Induced Seizures, Biomarkers of Oxidative Stress and Glutamate Decarboxylase Activity in Mice Basic Clin Neurosci. 2018 Nov-Dec; 9 (6): 389-96. PMID: 30719253.

28. Minns AB, Ghafouri N, Clark RF. Isoniazid-induced status epilepticus in a pediatric patient after inadequate pyridoxine therapy. Pediatr Emerg Care. 2010 May; 26 (5): 380-1. PubMed PMID: 20453796

29. Bernasconi R, Klein M, Martin P, Portet C, Maître L, Jones RS et al. The specific protective effect of diazepam and valproate against isoniazid-induced seizures is not correlated with increased GABA levels. J Neural Transm.1985; 63 (2): 169-89. PubMed PMID: 3930661. 